\title{
MONETARY POLICY AND THE CAUSALITY BETWEEN INFLATION AND MONEY SUPPLY IN INDONESIA
}

\author{
Gatot SASONGKO, Andrian Dolfriandra HURUTA
}

\author{
Faculty of Economics and Business, Universitas Kristen Satya Wacana, Salatiga, Indonesia \\ E-mails: gatot.sasongko@staff.uksw.edu (correspondingauthor); andrian.huruta@staff.uksw.edu
}

\author{
Received 06 February 2018; accepted 11 May 2018
}

\begin{abstract}
Conceptually and empirically, inflation volatility in Indonesia is a monetary and fiscal phenomenon. This study focuses on the macroeconomic policy and public policy especially causality between two variables namely inflation and money supply in Indonesia. This study uses Indonesian macroeconomic data of inflation and money supply from the Bank of Indonesia publication during 2007.1-2017.7. Inflation is measured by the consumer price index, reflects the annual percentage change in costs of acquiring a basket of goods and services to the average consumers that may change at specified intervals. Meanwhile, money supply is measured by the currency, demand deposits, time deposits, and saving deposits. Methodically, this study uses the Granger Causality model to determine the causality between inflation and money supply. The results show that there is a one-way causality between inflation and money supply in Indonesia. These findings imply that money supply causes inflation, but not vice versa. This condition implies that the role of Indonesian Government and Bank of Indonesia were very crucial in managing and controlling macroeconomic policy and public policy. Then, analysis of money supply and inflation also related to impacting factors such as money laundering, role of banks, taxation, tax evasion, and corruption.
\end{abstract}

Keywords: inflation, macroeconomic policy, money supply, public policy.

JEL Classification: E600, E610.

\section{Introduction}

The role of bureaucracy or government in the process of public policy is a necessity (Dwiyanto 1997). Since 2005, Bank of Indonesia has introduced a monetary policy framework that targets inflation as the main focus (Inflation Targeting Framework) with the free-floating exchange system. Consequently, a stable exchange rate is very important to support price and financial stability. In the implementation, Bank of Indonesia is authorized to make monetary policy by setting numerous monetary targets such as level of money supply (Bank Indonesia 2017d).

The economic crisis in Indonesia gave lessons that inappropriate policy will bring bad impact to the economy. The fact shows that by the end of 1997 there was a closure of 16 private banks. The closure of 16 private banks made public do not believe to the banking. Therefore they withdrew their savings from banks (see: Rush). Rush has caused an increase in the inflation rate (Hariyanto 2006). Indonesia underwent a monetary crisis in 1997 that caused the inflation rate to spike until 58\% in 1998 . However, the inflation rate returned to below two digits after the monetary crisis (see: recovery periods). Further, the latest global financial crisis in 2007 did not increase the inflation rate in Indonesia as indicated by the fact that the Indonesian inflation rate in 2008 was only $9.8 \%$, still below two digits (World Bank 2017). These conditions raise the following fundamental question: is reducing or achieving inflation a realistic target? We emphasize "reducing" because the Indonesian data show that the inflation rates in the past were higher than the current inflation rates. The following figure shows the inflation rate of Indonesia during 2007.1-2017.7 (after the global financial crisis).

Figure 1 shows that after the global financial crisis (during 2007.1-2017.7), inflation rate continued to fluctuate.

Copyright @ 2018 The Authors. Published by VGTU Press.

This is an Open Access article distributed under the terms of the Creative Commons Attribution License (http://creativecommons.org/licenses/by/4.0/), which permits unrestricted use, distribution, and reproduction in any medium, provided the original author and source are credited.. 


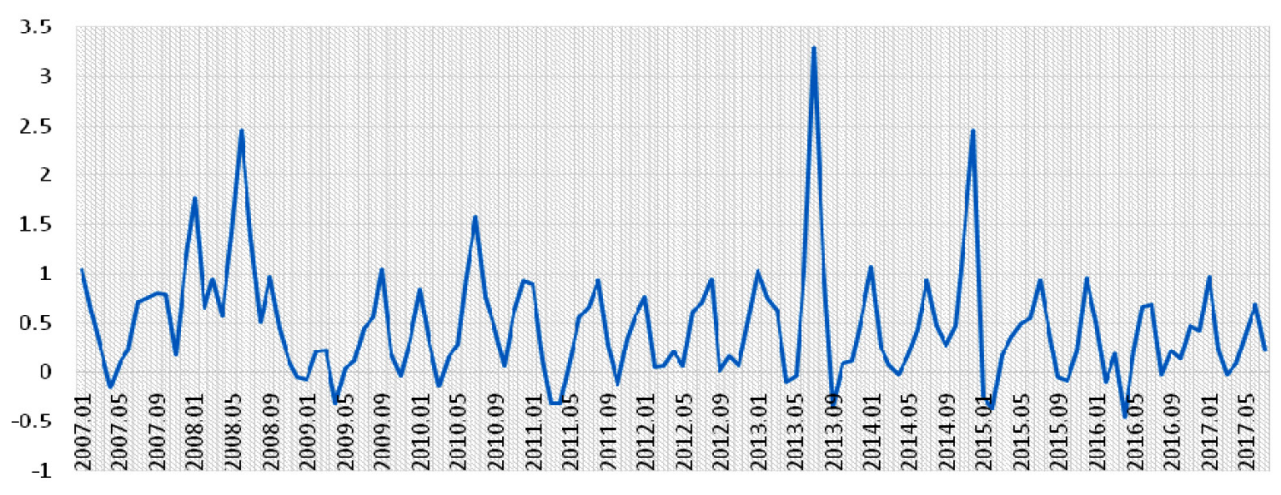

Figure 1. The Inflation Rate in Indonesia during 2007.1-2017.7 (source: Bank Indonesia 2017b)

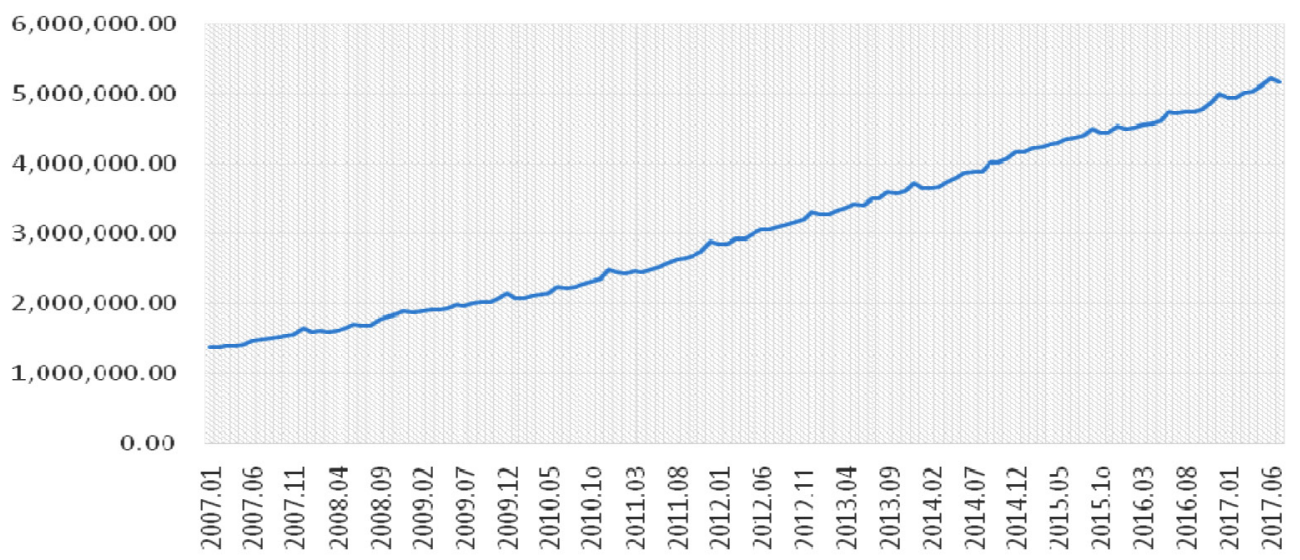

Figure 2. The Money Supply in Indonesia during 2007.1-2017.7 (source: Bank Indonesia 2017c)

However, after July 2013, the inflation rate tended to decline. This decline was possibly due to the Inflation Targeting Framework that was initiated by Bank of Indonesia since 2005 and the empowerment of the National Inflation Monitoring Team and the Regional Inflation Monitoring Teams in each region (at the province and municipality levels) to facilitate inflation controlling (Bank Indonesia 2017d).

Different from inflation, the money supply showed a positive trend during 2007.1-2017.7. Figure 2 below shows the money supply in Indonesia (after the global financial crisis).

Figure 2 shows the positive trend of the money supply during the observation period (2007.1-2017.7). The following are the likely factors of the increased level of money supply. First, Bank of Indonesia increased the level of foreign currencies to market. Consequently, the supply of Rupiah also increased. This factor indicates that the growth of money supply depends on the extent of the Bank of Indonesia's intervention. Bank of Indonesia announced that the money supply growth increased in April 2017. More specifically, the money supply position was Rp 5,042.1 trillion, increased by $10.0 \%(y-o-y)$.
This growth was higher than the $9.9 \%$ growth in previous month $(y-o-y)$. Further analysis reveals that the $8.7 \%$ growth of the quasi-money component $(y-o-y)$ that was higher than the growth in March 2017 that only reached 8.6\% (y-o-y) (Bank Indonesia 2017e). Secondly, the bank credit distribution accelerated because of an increase in credit demand from $52.9 \%$ in the first quarter to $84.8 \%$ in the second quarter of 2017 and increased again to $99.3 \%$ in the third quarter of 2017. This increase was mainly due to the improved economic condition and reduced risk of credit extension (Bank Indonesia 2017a). Third, the net foreign asset reached Rp 1,423.1 trillion or grew by $20.5 \%$ $(y-o-y)$, higher than the 17.6\% growth in March 2017 ( $y$ $o-y)$. This increase was in line with the increase of foreign exchange reserve in April 2017 (Bank Indonesia 2017e).

Conceptually and empirically, inflation volatility is the result of the high growth of money supply (Mishkin 2011). In other words, an increase in the money supply increases inflation rate or controlling the money supply can tame inflation rate (Jahan and Papageorgiou 2014). This study focuses on the macroeconomic policy and public policy especially causality between two variables namely inflation and money supply in Indonesia. 


\section{Literature review and theory perspective}

Previous studies have investigated the relationship between inflation and level of money supply. In Ethiopia, WoldeRufael (2008) uses the cointegration of Granger causality test method as modified by Toda and Yamamoto. The study empirically finds that there is a one-way causality from the money supply to inflation. The findings indicate that controlling the money supply is an important policy to preserve the long-term macroeconomic stability in Ethiopia. Chukwu (2013) also finds similar results in Nigeria. Using the same method as Wolde-Rufael (2008), the study empirically shows that there is a one-way causality from the growth of the money supply to the price level. The results suggest that the arithmetical hypothesis as proposed by Sargent and Wallace also applies in Nigeria. In Sri Lanka, Kesavarajah and Amirthalingam (2012) who use the multivariate cointegration of Johanson and Juseliues and Granger causality empirically indicate that there is a one-way causality from the money supply to inflation. The results suggest that inflation is the consequence of expansive monetary policy in Sri Lanka during the post-liberalization period. Further, the money supply is likely to be an effective policy instrument in preserving price stability in Sri Lanka. In Bangladeh, Amin (2011) who uses the Johansen's cointegration and Granger causality methods finds that there is a one-way causality from the money supply to inflation. The results support the monetarist' view that argues that inflation is a monetary phenomenon. More specifically, inflation increases because of weak implementation of monetary policy by the central bank of Bangladesh. Still, in the same country, Kashem and Sharmin (2012) who use the Granger cointegration and causality methods show that there is a one-way causality from the money supply to prices. The findings suggest that money supply stimulates price level not only in the long run but also in the short run. Consequently, Bangladesh has to design and implement their monetary policy prudently to control inflation rate more effectively. In China, Zhang (2013) uses the multivariate dynamic model from the money quantity theory of Friedman and the Meltzer's monetary model. The results suggest that there is a one-way causality between the money supply on inflation. This causality can be detected from the asset inflation. Consequently, the growth of money supply can be the most promising policy orientation to control inflation in China. Still in the same country, Su, Fan, Chang, and $\operatorname{Li}$ (2016) who use Granger causality show that there is a one-way relationship between growth of money supply to inflation. The findings are largely consistent with the modern money quantity theory from the perspective of the money supply and price level. This condition describes the stable growth of money supply and economic development in China.
Apart from the one-way causality, Denbel, Ayen, and Regasa (2016) who uses the cointegration method and Vector Error Correction Model (VECM) find that in the long run there is a two-way causality between inflation and the money supply. In other words, inflation affects the money supply and vice versa. The findings support the monetarist's view that holds that inflation is a monetary phenomenon. The results also imply that reducing the money supply decreases the inflation pressure in Ethiopia. Husain and Abbas (2000) also find similar findings in Pakistan. Using the cointegration method and Granger causality, they show that there is a two-way causality between the money supply with inflation. In other words, the money supply causes inflation and vice versa. It is then likely that the expansion of money supply increases price level and inflation that inflation eventually increases the money supply in Pakistan.

Previous studies use different analytical tools, such as Granger Causality, Sims Causality, and Vector Error Correction Model. Further, these studies also vary in their results. Many of the studies indicate a one-way causality such as Wolde-Rufael (2008), Chukwu (2013), Kesavarajah and Amirthalingam (2012), Amin (2011), Kashem and Sharmin (2012), Zhang (2013), Su et al., (2016). However, there are also several studies that show a two-way causality, such as Denbel et al., (2016) and Husain and Abbas (2000).

In Indonesia, several studies analyze inflation and level of money supply. For example, Hervino (2011) use the Autoregressive Distributed Lag Error Correction Model (ARDL-ECM). His study indicates that in the short run, increases in foreign debt and the amount of money supply even reduces the inflation rate. Meanwhile, in the long run, the inflation volatility in Indonesia is affected both by the fiscal and monetary factors although for the period after the 1997 economic crisis the monetary factor exhibits a greater effect on the inflation rate than the fiscal sector. The amount of money supply represents the monetary side while foreign debt to compensate national budget deficit represents the fiscal side.

Further, Trisdian, Pratomo, and Saraswati (2015) use the panel data regression (fixed effect model) that analyzes the variables of the money supply (measured by the amount of credit provided by banks and rural banks according to the project location) and inflation (measured by the yearon-year inflation rate for each province in Indonesia from 1999 to 2009). They find that regional inflation volatility in Indonesia is mainly caused by the monetary side (the money supply), not by the fiscal side (regional governments' debt). This research differs from the previous studies by using ARDL-ECM and panel data regression, and by combining regional and national data in their analysis.

Overall, previous studies show the use of various analytical tools such as Granger Causality, Sims Causality, 
Auto-Regressive Distributive Lag - Error Correction Model, Vector Error Correction Model, Panel Data, Vector Auto-Regressive; and the use of long-term and short-term data (monthly, annually, and quarterly). These studies also show various empirical findings (one-way causality, twoway causality, and no relationship between the money supply and inflation).

The change in the money supply simultaneously changes prices. This effect is based on the assumption that the velocity of money supply remains constant and the economy is under the condition of full employment. The following is the equation of money quantity as developed by Irving Fisher:

$$
M V=P T .
$$

Next, the following is the equation that forms the inflation theory:

$$
P=M V / T \text {. }
$$

The equations show that $\mathrm{M}$ is the money supply, $V$ is the velocity of money, $P$ is the price level, and $T$ is the number of goods and service transactions. It then can be argued from these equations that in general, a price increase is the consequence of an increase in the money supply.

The relationship between inflation and the money supply can also be explained by the monetarists through the perspective of Long-Run Monetary Neutrality. This perspective argues that each economy must experience inflation because the increase in money supply is always faster than the increase in national output. In other words, the inflation rate is affected by the money supply (Trisdian et al. 2015).

\section{Research methods}

We use the secondary data of inflation rate and the money supply from the Bank of Indonesia publication. The study uses the following econometric model with Granger causality model (Rosadi 2012).

$$
\begin{gathered}
X_{t}=\sum_{i=1}^{m} a_{i} X_{t-1}+\sum_{j=1}^{n} b_{j} Y_{t-1}+\mu_{t} ; \\
Y_{t}=\sum_{i=1}^{r} c_{i} X_{t-1}+\sum_{j=1}^{s} d_{j} Y_{t-1}+V_{t} .
\end{gathered}
$$

$X_{t}$ is the money supply, and $Y_{t}$ is inflation. Meanwhile, $\mu_{t}$ and $V_{t}$ are error terms that are assumed to exhibit no serial correlation, and $m=n=r=s$.

Before running the Granger Causality test, we need to run several tests such as stationary test and lag length test. The following is the model for stationary test:

$$
\Delta Y_{t}=\beta 1+\beta 2_{t}+\delta Y_{t-1}+u_{t} .
$$

Next, we select the optimal lag by selecting the smallest Akaike Information Criterion (AIC) score. Smaller AIC score indicates better model quality (Winarno 2015).

\section{Results}

Table 1 below displays the results of the stationary test or unit root test by using the Augmented Dickey-Fuller (ADF).

Table 1 suggests that inflation is stationary at the order of integration of $[\mathrm{I}(0)]$ while money supply is stationary at the second order of integration $[\mathrm{I}(2)]$. We then determine the optimal length of lag by using Lag Length Test as can be seen in Table 2.

Table 1. Unit root test

\begin{tabular}{|l|l|c|c|c|}
\hline \multicolumn{1}{|c|}{ Variable } & Order of Integration & ADF Statistic & Critical Value 5\% & Conclusion \\
\hline \multirow{2}{*}{ Inflation } & Level & -8.714167 & -2.884665 & $\mathrm{I}(0)$ \\
\hline \multirow{3}{*}{ Money Supply } & Level & 1.362404 & -2.886959 & Has Unit Root \\
\cline { 2 - 5 } & First Difference & 0.013869 & -1.943662 & Has Unit Root \\
\cline { 2 - 5 } & Second Difference & -7.865774 & -1.943662 & $\mathrm{I}(2)$ \\
\hline
\end{tabular}

Table 2. Lag length test

\begin{tabular}{|c|c|c|c|c|c|c|}
\hline Lag & LogL & LR & FPE & AIC & SC & HQ \\
\hline 0 & -1609.844 & NA & $1.59 \mathrm{e}+09$ & 26.86407 & 26.91053 & 26.88294 \\
\hline 1 & -1575.691 & 66.59839 & $9.63 \mathrm{e}+08$ & 26.36152 & 26.50090 & 26.41812 \\
\hline 2 & -1547.113 & 54.77488 & $6.40 \mathrm{e}+08$ & 25.95188 & 26.18418 & 26.04622 \\
\hline 3 & -1537.504 & 18.09801 & $5.83 \mathrm{e}+08$ & 25.85839 & 26.18360 & 25.99046 \\
\hline 4 & -1531.211 & 11.64039 & $5.61 \mathrm{e}+08$ & 25.82019 & 26.23831 & 25.98999 \\
\hline 5 & -1512.584 & $33.84027^{*}$ & $4.40 \mathrm{e}+08^{*}$ & $25.57640^{*}$ & $26.08744^{*}$ & $25.78393^{\star}$ \\
\hline
\end{tabular}

${ }^{*}$ indicates the optimal lag. 
Table 2 reveals that the optimal lag to describe the effect of the past variable or other endogenous variables to a variable is lag 5. The results of Granger Causality test can be seen in Table 3.

Table 3. Granger Causality Test

\begin{tabular}{|l|c|c|c|}
\hline \multicolumn{2}{|l|}{ Pairwise Granger Causality Tests } \\
\hline Sample: 1127 \\
\hline Lags: 5 & Obs & F-Statistic & Prob. \\
\hline Null Hypothesis: & 120 & 1.08938 & 0.3704 \\
\hline $\begin{array}{l}\text { Inflation does not Granger } \\
\text { Cause Money Supply }\end{array}$ & & 3.57865 & 0.0049 \\
\hline $\begin{array}{l}\text { Money Supply does not } \\
\text { Granger Cause Inflation }\end{array}$ & & & \\
\hline
\end{tabular}

Based on Table 3, it can be argued that there was only a one-way causality from the money supply to inflation in Indonesia during 2007.1-2017.7. These findings imply that the money supply causes inflation, but not vice versa. These studies support Wolde-Rufael (2008), Amin (2011), Kashem and Sharmin (2012), Kesavarajah and Amirthalingam (2012), Chukwu (2013), Zhang (2013) and Su et al. (2016). Our findings are likely due to the role separation between Bank of Indonesia and Financial Services Authority. The tasks of Bank of Indonesia are mainly regulating and supervising the banking industry from the macro-prudential side. More specifically, Bank Indonesia focuses on the banking system as the basis for making monetary policy, and controlling inflation and exchange rate. Meanwhile, Financial Services Authority supervises the banking industry from the micro-prudential side. Financial Services Authority focuses on direct supervision of banks individually and avoiding individual problems of banks that can harm banks' customers. Facts show that Bank of Indonesia continues to strengthen its macroprudential policy to reduce the systemic risk in the financial sector such as Financial System Stability. This policy aims to control credit and liquidity to facilitate the management of macroeconomic stability such as achieving inflation and unemployment target.

Other likely factors are (1) banks' activity or the intervention of Bank of Indonesia, (2) acceleration of the distribution of bank credits, (3) increased Net Foreign Asset, and (4) efforts to control food inflation to control price inflation of administered prices and volatile food. These factors are also facilitated by the coordination between Bank of Indonesia and the role of government (in the form of TPI and TPID) that boosted production, improved distribution and minimized price distortion of food prices. Accordingly, administered prices exhibited low inflation rate (even they potentially undergo deflation) because of decreased global energy prices amidst subsidy reformation through price adjustment of fuel, LPG $12 \mathrm{~kg}$, and electricity rate. Further, the low inflation rate of the administered prices was likely due to the government's effort to decrease diesel fuel and to provide electricity tariff discount for certain industry categories through the economic policy. The core inflation was constantly under control because of the support from controlled expected inflation as a consequence of the passthrough of limited weakening of exchange rate and relatively weak domestic demand pressure. Lastly, the Bank of Indonesia's policy in managing domestic demand, preserving the stability of exchange rate and directing expected inflation also supported the condition (Bank Indonesia 2015).

The following fact (see: Figure 3) that indicates the oneway relationship between inflation and the money supply during 2007.1-2017.7 also supports our findings. The following is the relationship between inflation and the money supply (after the global financial crisis).

Figure 3 shows that there was an increase of the money supply during 2007.1-2017.7. At the same time, inflation fluctuated. Initially, inflation increased, but since 2013 it tended to decrease. According to the theory of money quantity, inflation emerges only when there is an increase in money supply. In other words, when there is no increase in the money supply, there will be no price increase. The condition described in Figure 3 is in line with the theory

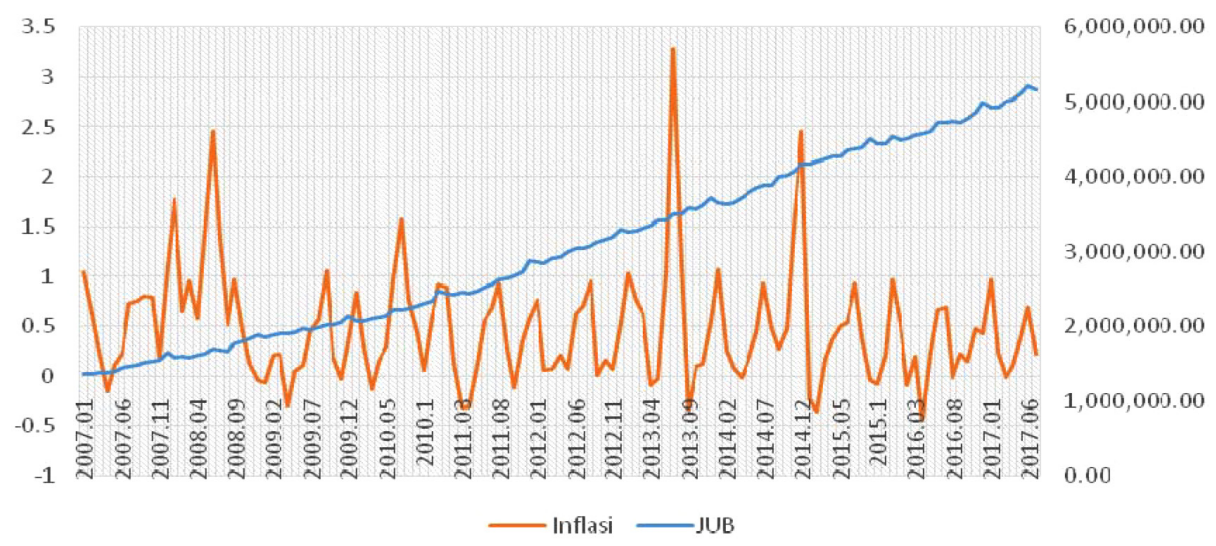

Figure 3. The Relationship between Inflation and Money Supply during 2007.1-2017.7 (source: Bank Indonesia 2017b, 2017c) 
of money quantity and the long-run monetary neutrality. In other words, during 2007.1-2017.7, the Indonesian economy was sensitive to the monetary policies, especially those related to money supply. This condition implies that the role of Indonesian Government and Bank of Indonesia were very crucial in managing and controlling public policy.

From the macroeconomic policy and public policy perspective, the combination of various monetary, fiscal, and real policies is important in anticipating the effect of the global financial crisis. Regarding monetary policy, the government through Bank of Indonesia needs to regulate monetary policy instruments such as open market policy, reserve requirement, discount facility, and moral suasion to achieve the monetary targets as set by the monetary authority. It then can be expected that the money supply can be used as an effective macroeconomic policy and public policy instrument to preserve price stability in Indonesia.

Analysis of money supply and inflation also related to impacting factors such as money laundering (Kordík and Kurilovská 2017), role of banks (Kaźmierczyk and Aptacy 2016), taxation (Giriūnienè and Giriūnas 2016, Bikas et al. 2017), tax evasion, and corruption (Luzgina 2017). In Indonesia, money launderers have used an increasingly varied mode by utilizing institutions outside the financial system, and even has penetrated into various sectors. Therefore, it is necessary to have synergy and equality of perception among Law Enforcement Officials in order to prevent and combat money laundering and terrorism financing (Pusat Pelaporan dan Analisis Transaksi Keuangan 2016).

Money laundering will have an impact to unexplainable changes in the money supply, international capital flows, interest, and exchange rates. Related to money supply, the unpredictable nature of money laundering can lead to distortions and economic instability. Related to this fact, Kordík and Kurilovská (2017) finds that money laundering or terrorism financing risks is an essential part of the implementation and development of a national anti-money laundering or countering the financing of terrorism regime, which includes laws, regulations, enforcement and other measures to mitigate money laundering or terrorism financing risks.

Next, the role of Bank of Indonesia as the Central Bank is very important. Bank of Indonesia play a role as supervisor and coach to increase the confidence of everyone who has an interest in the bank. In particular, banking performance has seen as an intermediary institution. The growth of banks third party funds and credit (2010-2017) can be seen in Table 4.

The growth of the placement of Third Party Fund has decreased from $18.54 \%$ in 2010 to $7.26 \%$ in 2015, but in 2016 (December) increased to $9.26 \%$ and tends to increase during 2017. Next, the credit disbursement showed a different
Table 4. The Growth of Banks Third Party Funds and Credit (2010-2017) (source: Otoritas Jasa Keuangan (2017))

\begin{tabular}{|c|c|c|c|c|}
\hline Date & $\begin{array}{c}\text { Third Party } \\
\text { Funds (Rp) }\end{array}$ & $\begin{array}{c}\text { Growth } \\
(\%)\end{array}$ & $\begin{array}{c}\text { Credit } \\
(\mathrm{Rp})\end{array}$ & $\begin{array}{c}\text { Growth } \\
(\%)\end{array}$ \\
\hline 2010 & 2.338 .824 & 18.54 & 1.765 .845 & 22.80 \\
\hline 2011 & 2.784 .912 & 19.07 & 2.200 .095 & 24.59 \\
\hline 2012 & 3.225 .199 & 15.81 & 2.707 .862 & 23.08 \\
\hline 2013 & 3.663 .967 & 13.60 & 3.292 .874 & 21.60 \\
\hline 2014 & 4.114 .420 & 12.29 & 3.674 .308 & 11.58 \\
\hline 2015 & 4.413 .056 & 7.26 & 4.057 .904 & 10.44 \\
\hline 2016 & 4.836 .758 & 9.60 & 4.377 .195 & 7.87 \\
\hline Jan 2017 & 4.825 .336 & 10.04 & 4.312 .991 & 8.28 \\
\hline Feb 2017 & 4.846 .420 & 9.21 & 4.308 .081 & 8.57 \\
\hline Mar 2017 & 4.916 .665 & 10.02 & 4.369 .967 & 9.24 \\
\hline Apr. 2017 & 4.920 .453 & 9.87 & 4.386 .031 & 9.47 \\
\hline May 2017 & 5.012 .456 & 11.18 & 4.425 .154 & 8.71 \\
\hline Jun 2017 & 5.045 .987 & 10.30 & 4.491 .186 & 7.75 \\
\hline
\end{tabular}

results. Since 2010, the credit disbursement has continued to decline. The credit disbursement was $22.80 \%$ in 2010 , and continued to fall to $7.87 \%$ in 2017 . Overall, the increasing trend of Third Party Funds has not been followed by fund disbursement. It Implies that the financial performance in banking sector must be improved. Therefore Kaźmierczyk and Aptacy (2016) suggest that banks need to apply management by objectives to create rewarding plans for the achievement of objectives.

Another influential factor is the misuse of office in the form of corruption. In Indonesia, corruption is still apprehensive. The corruption data are divided into five stages such as probing, investigation, prosecution, incrach, and execution. The data description can be seen in Table 5 .

The five stages of corruption handling show an improvement in growth. Although fluctuating, for 14 years the number of corruption continues to increase. Corruption causes income to be more than it should be, so that will affect the money supply. The money supply will increase as corruption gets higher and vice versa. Related to this fact, Luzgina (2017) suggest that to reduce corruption and tax evasion should be done not only on punishment, but on creating attractive environment for business development and reducing stimulus for corruption and tax evasion.

Besides money laundering, role of banks, tax evasion, and corruption, analysis of money supply and inflation can be explained from taxation. In Indonesian case, based on Non-Taxable Income number 101 of 2016, the amount of the new non-taxable income is an implementation of the changes contained in Regulation of the Minister of Finance Number 101/PMK.010/2016. This adjustment takes effect from January 2016. The increase of non-taxable income is expected to have a good impact on the level of tax revenue. 
Table 5. The growth of five stages of corruption in Indonesia (source: Komisi Pemberantasan Korupsi (2017))

\begin{tabular}{|c|c|c|c|c|c|c|c|c|c|c|}
\hline \multirow{2}{*}{ Year } & \multicolumn{2}{|c|}{ Probing } & \multicolumn{2}{c|}{ Investigation } & \multicolumn{2}{c|}{ Prosecution } & \multicolumn{2}{|c|}{ Incrach } & \multicolumn{2}{c|}{ Excecution } \\
\cline { 2 - 12 } & Amount & Change (\%) & Amount & Change (\%) & Amount & Change (\%) & Amount & Change (\%) & Amount & Change (\%) \\
\hline 2004 & 23 & - & 2 & - & 2 & - & - & - & - & - \\
\hline 2005 & 29 & 26 & 9 & 350 & 17 & 750 & 5 & - & 4 & - \\
\hline 2006 & 36 & 24 & 27 & 200 & 23 & 35 & 14 & 180 & 13 & 225 \\
\hline 2007 & 70 & 94 & 24 & -11 & 19 & -17 & 19 & 36 & 23 & 77 \\
\hline 2008 & 70 & 0 & 47 & 96 & 35 & 84 & 23 & 21 & 24 & 4 \\
\hline 2009 & 67 & -4 & 37 & -21 & 32 & -9 & 37 & 61 & 37 & 54 \\
\hline 2010 & 54 & -19 & 40 & 8 & 32 & 0 & 34 & -8 & 36 & -3 \\
\hline 2011 & 78 & 44 & 39 & -3 & 40 & 25 & 34 & 0 & 34 & -6 \\
\hline 2012 & 77 & -1 & 48 & 23 & 36 & -10 & 28 & -18 & 32 & -6 \\
\hline 2013 & 81 & 5 & 70 & 46 & 41 & 14 & 40 & 43 & 44 & 38 \\
\hline 2014 & 80 & -1 & 58 & -17 & 50 & 22 & 45 & 13 & 48 & 9 \\
\hline 2015 & 87 & 9 & 57 & -2 & 62 & 24 & 38 & -16 & 38 & -21 \\
\hline 2016 & 96 & 10 & 99 & 74 & 76 & 23 & 71 & 87 & 81 & 113 \\
\hline 2017 & 123 & 28 & 121 & 22 & 103 & 36 & 84 & 18 & 85 & 5 \\
\hline & 971 & 17 & 678 & 59 & 568 & 75 & 472 & 35 & 499 & 41 \\
\hline & Total & Average & Total & Average & Total & Average & Total & Average & Total & Average \\
\hline
\end{tabular}

Although there will be a decrease in taxable income, this new implementation will increase tax revenue from Value Added Tax, Sales Tax on Luxury Goods and Corporate Income Tax. Ultimately, micro tax revenues will fall, but people's purchasing power will rise (Hadijah 2016). As a policy instrument in the field of taxation, Non-Taxable Income has a close association with personal income tax. Increase in Non-Taxable Income makes the smaller taxes paid by households. This condition resulted in households will have more money to make investments or savings. Related to this fact, Giriūnienè and Giriūnas (2016) suggest that the country which taking into account its specific characteristics, can compose the suitable complex tax system evaluation model. It can help to evaluate the country's tax system in the most objectively way. Then, Bikas et al. (2017) suggest that taxation especially value-added tax have a significant role in the tax system and the impact of value-added tax revenue on the state budget.

\section{Conclusions}

Our study shows that there is a one-way causality between inflation and money supply in Indonesia during 2007.1-2017.7. This causality is mainly due to the Inflation Targeting Framework set by the role of Indonesian government and Bank of Indonesia, the increased function of the Regional Inflation Monitoring Team in each region, the role separation between Bank of Indonesia in the macro prudential side and Financial Service Authority from the micro prudential side, banks' activities or the intervention of Bank of Indonesia, acceleration of bank credit distribution, an increase in Net Foreign Assets, control of food inflation to anticipate administered prices and volatile food, and the effect of the central banks of other countries. It then can be concluded that the money supply can be used as an effective public policy instrument in preserving price stability in Indonesia. Next, analysis of money supply and inflation also related to impacting factors such as money laundering, role of banks, taxation, tax evasion, and corruption.

We only observe during 2007.1-2017.7 that limits the generalization of our findings to public policy especially the causality of inflation and the money supply in Indonesia for the whole periods. Therefore, we recommend that further research could use inflation data from the supply side and use the longer observation period by using the cointegration test of Johansen.

\section{References}

Amin SB (2011) Quantity theory of money and its applicability: the case of Bangladesh. World Review of Business Research 1 (4): 33-43 https://www.researchgate.net/publication/305493357_Quantity_Theory_of_Money_and_its_Applicability_The_Case_of_Bangladesh

Bank Indonesia (2015) BI dan Pemerintah Sepakati Langkah Untuk Jaga Inflasi 2016. Bank Indonesia http://www.bi.go.id/ id/ruang-media/siaran-pers/Pages/sp_179615.aspx

Bank Indonesia (2017a) Bank survey during the second quarter of 2017: new credit growth is estimated to increase in the third quarter of 2017. Communication Department http://www. bi.go.id/en/ruang-media/info-terbaru/Pages/PertumbuhanKredit-Baru-Diperkirakan-Semakin-Meningkat-pd-TwIII-2017.aspx 
Bank Indonesia (2017b) Laporan Inflasi (Indeks Harga Konsumen). Bank Indonesia https://www.bi.go.id/id/moneter/ inflasi/data/Default.aspx

Bank Indonesia (2017c) Statistik Ekonomi dan Keuangan Indonesia (SEKI). Bank Indonesia https://www.bi.go.id/id/statistik/ seki/terkini/moneter/Contents/Default.aspx

Bank Indonesia (2017d) Tujuan Kebijakan Moneter Bank Indonesia. Bank Indonesia http://www.bi.go.id/id/moneter/ tujuan-kebijakan/Contents/Default.aspx

Bank Indonesia (2017e) Uang Beredar Tumbuh Meningkat pada April 2017. Bank Indonesia http://www.bi.go.id/id/ ruang-media/info-terbaru/Pages/Uang-Beredar-TumbuhMeningkat-pada-April-2017.aspx

Bikas E, Bagotyrius G, Jakubauskaite A (2017) The impact of value-added tax on the fiscal sustainability. Journal of Security and Sustainability Issues 7 (2): 267-285. https://doi. org/10.9770/jssi.2017.7.2(8)

Chukwu JO (2013) Budget deficits, money growth and price level in Nigeria. African Development Review 25 (4): 468-477. https://doi.org/10.1111/1467-8268.12042

Denbel FS, Ayen YW, Regasa TA (2016) The relationship between inflation, money supply and economic growth in Ethiopia: Co integration and Causality Analysis. International Journal of Scientific and Research Publications 6 (1): 556-565 www. ijsrp.org

Dwiyanto A (1997) Pemerintah Yang Efisien, Tanggap dan Akuntabel: Kontrol atau Etika?. Jurnal Kebijakan dan Administrasi Publik 1 (2): 1-14 http://i-lib.ugm.ac.id/jurnal/detail. php? dataId $=7880$

Giriūnienè G, Giriūnas L (2016) Identification of the complex tax system evaluation criteria: theoretical aspect. Journal of Security and Sustainability Issues 7 (2): 77-85.

Hadijah S (2016) Penghasilan Tidak Kena Pajak (PTKP), Apa Itu? https://www.cermati.com/artikel/penghasilan-tidak-kenapajak-ptkp-apa-itu

Hariyanto E (2006) Efek dan Dampak Kebijakan Debt Switching Terhadap Keuangan Negara. Jurnal Kebijakan dan Administrasi Publik 10 (1): 65-96 https://journal.ugm.ac.id/jkap/ article/view/8319/6428.

Hervino AD (2011) Volatilitas inflasi di indonesia: fiskal atau moneter? Finance and Banking Journal 13 (2): 669-672 https:// perbanas.id/jurnal/index.php/jkp/article/view/254

Husain F, Abbas K (2000) Money, Income, prices, and causality in Pakistan: a trivariate analysis 178 https://ideas.repec.org/p/ $\mathrm{pid} /$ wpaper/2000178.html

Jahan S, Papageorgiou C (2014) What is monetarism? Its emphasis on money's importance gained sway in the 1970s. Finance \& Development (March): 38-39 http://www.imf.org/external/ pubs/ft/fandd/2014/03/pdf/basics.pdf

Kashem MA, Sharmin H (2012) A study of causality between money supply and price level in Bangladesh: 1976 to 2012 https://www.academia.edu/7688356/A_Study_of_Causality_between_Money_Supply_and_Price_Level_in_Bangladesh_1976_to2012
Kaźmierczyk J, Aptacy M (2016) The management by objectives in banks: the Polish case. Entrepreneurship and Sustainability Issues 4 (2): 1-13. https://doi.org/10.9770/jesi.2016.4.2(3)

Kesavarajah M, Amirthalingam K (2012) The nexus between money supply and inflation in Sri Lanka. Jaffna University International Research Conference, 232 http://www.conf. jfn.ac.lk/juice2012/papers/TrackI/JUICE12-TrackI-pg232.pdf

Komisi Pemberantasan Korupsi (2017) Laporan Tahunan KPK, Komisi Pemberantasan Korupsi https://www.kpk.go.id/id/.../ laporan.../4172-laporan-tahunan-kpk-2

Kordík M, Kurilovská L (2017) Protection of the national financial system from the money laundering and terrorism financing. Entrepreneurship And Sustainability Issues 5 (2): 243-262. https://doi.org/10.9770/jesi.2017.5.2(7)

Otoritas Jasa Keuangan (2017) Laporan triwulanan III 2017, Otoritas Jasa Keuangan https://www.ojk.go.id/id/data-danstatistik/laporan-triwulanan/Documents/Laporan Triwulan OJK III-2017.pdf

Luzgina A (2017) Problems of corruption and tax evasion in construction sector in Belarus. Entrepreneurship And Sustainability Issues 5 (2): 263-282. https://doi.org/10.9770/ jesi.2017.5.2(8)

Mishkin FS (2011) Monetary policy strategy: lessons from the crisis. 16755. Cambridge http://www.nber.org/papers/w16755

Pusat Pelaporan dan Analisis Transaksi Keuangan (2016) Tipologi Pencucian Uang Berdasarkan Putusan Pengadilan Tahun 2015 http://www.ppatk.go.id//backend/assets/images/ publikasi/1484876309_.pdf

Rosadi D (2012) Ekonometrika dan Analisis Runtun Waktu Terapan Dengan Eviews. Yogyakarta: ANDI.

$\mathrm{Su} \mathrm{C}-\mathrm{W}$ et al. (2016) Is there causal relationship between money supply growth ad inflation in China? Evidence from quantity theory of money. Review of Development Economics 20 (3): 702-719 https://onlinelibrary.wiley.com/doi/pdf/10.1111/ rode. 12194

Trisdian PA, Pratomo Y, Saraswati BD (2015) Volatilitas Inflasi Daerah di Indonesia: Fenomena Moneter atau Fiskal. KRITIS, Jurnal Studi Pembangunan Interdisiplin XXIV(1): 76-89 http://ejournal.uksw.edu/kritis/article/view/493/327

Winarno WW (2015) Analisis Ekonometrika dan Statistika dengan Eviews (4th ed) Yogyakarta: UPP STIM YKPN.

Wolde-Rufael Y (2008) Budget deficits, money and inflation: the case of Ethiopia. The Journal of Developing Areas 42 (1): 183-199 https://muse.jhu.edu/article/252005/pdf

World Bank (2017) World Bank Reports, World Bank http://www. worldbank.org/en/region/eca/brief/office-of-the-chief-economist-europe-andcentralasia?cid=ECA_GA_ECA_EN_EXT P\&gclid=EAIaIQobChMIxZ2jxMeo1QIVVAoqCh0jzwSzEA AYASAAEgIHhvD_BwE

Zhang C (2013) Monetary dynamics of inflation in China. The World Economy 36 (6) http://onlinelibrary.wiley.com/ doi/10.1111/twec.12021/pdf 